\title{
Predictors of Direct-Acting Antivirals Failure in Patients with Chronic Hepatitis C Virus in Ivory Coast: About 5 Cases
}

\author{
Dimitri Hatrydt Kouamé*, Stanislas Adjéka Doffou, Henriette Kissi Anzouan-Kacou, \\ Yannick Mfupa Tchana, Aboubakar Demba Bangoura, Mahassadi Kouamé Alassan, \\ Fulgence Bathaix Yao, Alain Koffi Attia, Thérèse Ndri Yoman
}

Hepatogastroenterology Unit, Yopougon Teaching Hospital, Yopougon, Côte d'Ivoire

Email: *hatry333@gmail.com

How to cite this paper: Kouamé, D.H., Doffou, S.A., Anzouan-Kacou, H.K., Tchana, Y.M., Bangoura, A.D., Alassan, M.K., Yao, F.B., Attia, A.K. and Yoman, T.N. (2019) Predictors of Direct-Acting Antivirals Failure in Patients with Chronic Hepatitis C Virus in Ivory Coast: About 5 Cases. Open Journal of Gastroenterology, 9, 193-201.

https://doi.org/10.4236/ojgas.2019.910022

Received: September 13, 2019

Accepted: October 25, 2019

Published: October 28, 2019

Copyright $\odot 2019$ by author(s) and Scientific Research Publishing Inc. This work is licensed under the Creative Commons Attribution International License (CC BY 4.0).

http://creativecommons.org/licenses/by/4.0/ (c) (i) Open Access

\begin{abstract}
Context and Aim: Direct-acting antivirals are the therapeutic revolution in the management of viral hepatitis $C$, but often with a few cases of failure. The aim of this study was to identify factors that may be implicated in the failure of direct-acting antiviral therapy in patients with hepatitis $\mathrm{C}$ virus in Ivory Coast. Methodology: This was a cross-sectional and descriptive study with a retrospective compendium of data from the year 2016 to the year 2018. This study included all patients with chronic viral hepatitis $C$, patients naive to antiviral treatment, or pre-treated patients in whom a failure to treatment with direct-acting antiviral has been diagnosed. Results: During the study period, 5 patients out of 14 cases of therapeutic failure were included, i.e. $35.71 \%$. Most of the patients were over 50 years ( 4 out of 5 ) and predominantly female ( 3 out of 5). High blood pressure was the most common comorbidity (3 out of 5 patients). Genotype 1 was found in 4 patients versus 1 case of genotype 2 . None of the patients had hepatitis B or HIV coinfection. A viral load $>6 \log$ was found in 4 patients at baseline. All our patients had hepatic cytolysis. Two of them were cirrhotic. All 4 cases of genotype 1 benefited from the combination sofosbuvir + ledipasvir for 12 weeks and the case of genotype 2 from the combination sofosbuvir + ribavirin for 24 weeks. The resistance mutations were observed mainly on the sequencing of NS5A at the $\mathrm{Y} 93 \mathrm{H}$, L31M, 28L, 30T, $31 \mathrm{~V}, 58 \mathrm{~S}$ and $93 \mathrm{H}$ genes and a case of mutation on the N3 gene sequencing. Conclusion: Age $>50$ years, comorbidities (high blood pressure), polymedication, female gender, genotype $1 \mathrm{~b}$, viremia $>6 \log$, and cytolysis were the profile of patients with treatment of HCV by direct-acting antiviral failure.
\end{abstract}




\section{Keywords}

HVC, Direct-Acting Antivirals, Failure, Ivory Coast

\section{Introduction}

Infection with the hepatitis $\mathrm{C}$ virus is a public health problem due to its prevalence, morbidity and mortality. It is a cosmopolitan affection with geographical disparities. It affects about 71 million people worldwide, making it one of the leading causes of chronic liver disease [1] [2]. There are approximately 399,000 deaths each year due to cirrhosis of viral hepatitis $\mathrm{C}$ origin and its complications [2] [3]. The prevalence of hepatitis $C$ virus infection in the African region is estimated at about $1 \%$ of the population (11 million inhabitants) with a peak frequency in North Africa especially in Egypt [2] [4]. In Ivory Coast it is estimated at 5\% [5] [6]. There is still no vaccine against the hepatitis $C$ virus. Control of this pandemic and its complications requires strict adherence to preventive measures and hepatitis $\mathrm{C}$ antiviral treatment in infected patients. The main objective of this treatment is the cure of HCV infection, i.e. the achievement of a sustained virological response (SVR) defined by undetectable HCV viral load 12 weeks (SVR12) or 24 weeks (RVS24) after the end of treatment [1]. A few years ago, the treatment was based on the combination of therapy pegylated interferon (PegIFN) and ribavirin (RBV). In view of the low success rate associated with the numerous side effects that are not always easy for the practitioner to manage, a new therapeutic class was introduced in 2014: direct-acting antivirals [7]-[12]. Their action on the HCV genome results in a high sustained virological response rate, shorter treatment times, and fewer side effects [6]. However, their high cost is a barrier to their access in countries with limited resources such as Ivory Coast.

In addition, failures to treatment with direct-acting antiviral (DAA), although rare, have been observed [7]. These failures will lead to the emergence of resistance mutations resulting in reduced efficacy of some combination regimens of DAAs [6] [10] [12]. In the absence of the potential causes of failure (nonobservance, drug interactions, premature discontinuation, non-optimal regimen), it is recommended to perform a test for resistance mutations in order to readjust the treatment [13]. The high cost and inaccessibility of resistance mutation testing in Ivory Coast, likewise other low-income countries, limits its prescription by many practitioners in cases of non-response or relapses following hepatitis $\mathrm{C}$ antiviral treatment by DAAs. No studies have been done on the failure of direct-acting antiviral therapy in patients with HCV in sub-Saharan Africa. In Ivory Coast, direct-acting antivirals were introduced into the hepatitis $\mathrm{C}$ therapeutic arsenal in 2015. We observed resistance among patients receiving this treatment in the hepatogastroenterology department of Abidjan. We therefore consider it opportune to focus on this problem of failure of hepatitis $\mathrm{C}$ treatment by these last-generation molecules, the objective being to describe the clinical and parac- 
linical profile of patients who have failed treatment with the hepatitis $C$ virus.

\section{Patients and Methodology}

It was a cross-sectional and descriptive study with a retrospective collection of data from 1 January 2016 to 1 September 2018 in public and private medical facilities in Abidjan. Included in this study were all patients with chronic viral hepatitis $\mathrm{C}$, patients naive to antiviral treatment, or pre-treated and receiving direct-acting antiviral treatment during the study period. Only patients who have failed diagnosis of direct-acting antivirals have been selected for any genotype or stage of fibrosis. Not included in this study:

- Patients with chronic viral hepatitis $\mathrm{C}$ treated with direct-acting antivirals presenting treatment failure but declined to participate in the study.

- Patients with chronic viral hepatitis $\mathrm{C}$ treated with direct-acting antivirals who were not observant with the treatment.

- Patients with viral hepatitis $C$ treated with direct-acting antivirals who have failed treatment but who have not performed a resistance mutation test.

All genotypes of the hepatitis $C$ virus were involved regardless of the stage of liver fibrosis of the patient. The failure of direct-acting antiviral treatment was defined as follows [12]:

Non-responders: decrease in viral load $<2 \log$ at 12 weeks of treatment-slow responders: viral load drops significantly $>2 \log$ at 12 weeks of treatment but detectable during treatment and detectable at 24 weeks of treatment-responders-escapers or escape: the viral load becomes undetectable during treatment but detectable at the end of treatment-relapsing responders: the viral load becomes undetectable at the end of treatment but it reappears 3 to 6 months after it is stopped.

The therapeutical regimens available and used in Ivory Coast at the time of the study were:

1) Sofosbuvir $400 \mathrm{mg}$ (SFV) combined with Ribavirin $400 \mathrm{mg}$ (1000 mg if the weight of the patient $<75 \mathrm{~kg}$ and $1200 \mathrm{mg}$ if the weight of the patient $>$ or equal $75 \mathrm{~kg}(\mathrm{RBV})$;

2) Sofosbuvir $400 \mathrm{mg}$ combined with Ledipasvir $90 \mathrm{mg}$ (LDV) in fixed combination;

3) Sofosbuvir $400 \mathrm{mg}$ combined with Daclastavir 30 to $60 \mathrm{mg}$-Sofosbuvir 400 $\mathrm{mg}$ combined with Velpatasvir $100 \mathrm{mg}$ in fixed combination.

The follow-up for the evaluation of the effectiveness during the treatment was carried out by the transaminase monitoring and the hepatitis $C$ viral load at 4 weeks and at the end of treatment, then after the end of treatment with transaminase monitoring and viral hepatitis $\mathrm{C}$ viral load at 12 weeks and at 24 weeks. The tolerance of treatment was monitored by biologic followal (hemogram and serum creatinine at M1, M3 and M6). Resistance mutation research was carried out in 2 different laboratories in France (Laboratory of virology of the University Hospital of DIJON and Cerba Pasteur Paris). The molecules tested were the following: anti NS5A (Daclastavir, Ledipasvir, Ombitasvir, Pibrentasvir, Velpatasvir, Elbasvir), anti NS5B (Sofosbuvir, Dasabuvir) and anti NS3 (Simeprevir, Pa- 
ritaprevir, Grazoprevir, Glecaprevir, Voxilaprevir). The Data collection was carried out using a pre-established form by consulting the medical file of each case and the assessments made during the treatment. The data was collected under Windows 8 using Microsoft Office Word 2010 software.

The research was done according to the principles of Helsinski's statement.

\section{Results}

From January 1, 2016 to September 1, 2018, we identified 14 cases of treatment failure with direct-acting antiviral including 11 patients infected with genotype 1 and 3 patients with genotype 2. Patients included are those who were observant to direct-acting antiviral drug therapy and having undergone a resistance mutation test, i.e. 5 patients (35.71\%). Patients were predominantly women (3 out of 5 ) with an average age of over 50 years. Genotype $1 \mathrm{~b}$ was the predominant genotype (4 out of 5 patients) and no patient had HBV-HIV coinfection. The majority of patients (4 out of 5) had a viral load $>6 \log$ at recruitment. Two of our patients had cirrhosis (F4) before direct-acting antiviral therapy, two had fibrosis F2, and one had F1. Only one patient was pre-treated before direct-acting antiviral therapy. Sofosbuvir and Ledipasvir was the predominantly used therapeutic combination (in 4 out of 5 patients). Two drugs that may interact with direct-acting antiviral drugs have been noted (a Proton Pump Inhibitor and a Calcium channel Inhibitor). According to the characteristics of the resistance mutation tests, the mutation was greater on the NS5A gene observed in 4 out of 5 patients (Table 1).

Table 1. Cases summary.

\begin{tabular}{|c|c|c|c|c|c|c|c|c|c|c|c|c|c|c|c|}
\hline & Age & Sex & BMI & G & $\begin{array}{c}\text { Viral load } \\
(\log )\end{array}$ & $\mathrm{F}$ & Statut & DAA & $\begin{array}{c}\text { Posology } \\
\text { DAA }\end{array}$ & $\begin{array}{c}\text { Duration } \\
\text { (weeks) }\end{array}$ & Drug inter & $\begin{array}{l}\text { Failure } \\
\text { moment }\end{array}$ & $\begin{array}{c}\text { VR } \\
\text { NS3 }\end{array}$ & $\begin{array}{c}\text { VR } \\
\text { NS5A }\end{array}$ & Drugs resistance \\
\hline P1 & 42 & M & 18 & $1 \mathrm{~b}$ & 5,3 & $\mathrm{~F} 1$ & Naïve & $\begin{array}{c}\text { SOF } \\
+ \\
\text { LED }\end{array}$ & $\begin{array}{c}400 \mathrm{mg} / \mathrm{jr} \\
+ \\
90 \mathrm{mg} / \mathrm{jr}\end{array}$ & 12 & No & $\begin{array}{l}\text { M6 post- } \\
\text { Treatment }\end{array}$ & none & $\begin{array}{c}\text { Y93H } \\
\text { L31M+ }\end{array}$ & LED \\
\hline $\mathrm{P} 2$ & 71 & $\mathrm{~F}$ & 22 & $2 \mathrm{~L}$ & 6,31 & $\mathrm{~F} 4$ & Naïve & $\begin{array}{c}\text { SOF } \\
+ \\
\text { RBV }\end{array}$ & $\begin{array}{c}400 \mathrm{mg} / \mathrm{jr} \\
+ \\
800 \mathrm{mg} / \mathrm{jr}\end{array}$ & 24 & No & $\begin{array}{l}\text { M6 post- } \\
\text { Treatment }\end{array}$ & none & $\begin{array}{c}\text { Not } \\
\text { amplifiable }\end{array}$ & \\
\hline P3 & 60 & $\mathrm{~F}$ & 21 & $1 b$ & 6,15 & $\mathrm{~F} 2$ & Naïve & $\begin{array}{c}\text { SOF } \\
+ \\
\text { LED }\end{array}$ & $\begin{array}{c}400 \mathrm{mg} / \mathrm{jr} \\
+ \\
90 \mathrm{mg} / \mathrm{jr}\end{array}$ & 12 & No & $\begin{array}{l}\text { M3 post- } \\
\text { Treatment }\end{array}$ & none & $\begin{array}{c}28 \mathrm{~L}, 30 \mathrm{~T} \\
31 \mathrm{~V}, 58 \mathrm{~S} \\
93 \mathrm{H}\end{array}$ & $\begin{array}{l}\text { LED, DACLA, } \\
\text { VELPA, ELBAS } \\
\text { OMBIT, PIBR } \downarrow\end{array}$ \\
\hline $\mathrm{P} 4$ & 82 & $\mathrm{~F}$ & 28 & $1 \mathrm{~d}$ & 6 & $\mathrm{~F} 2$ & Naïve & $\begin{array}{c}\text { SOF } \\
+ \\
\text { LED }\end{array}$ & $\begin{array}{c}400 \mathrm{mg} / \mathrm{jr} \\
+ \\
90 \mathrm{mg} / \mathrm{jr}\end{array}$ & 12 & $\begin{array}{l}\text { yes } \\
\text { PPI }\end{array}$ & $\begin{array}{c}\text { During } \\
\text { treatment } \\
\text { (M3) }\end{array}$ & none & $\begin{array}{c}28 \mathrm{~V}, 30 \mathrm{~A} \\
93 \mathrm{~N}\end{array}$ & $\begin{array}{c}\text { LED, DACLA, } \\
\text { ELBAS } \\
\text { VELPA } \downarrow, \text { PIBR } \downarrow\end{array}$ \\
\hline P5 & 56 & M & 28 & $1 b$ & 6,43 & $\mathrm{~F} 4$ & $\begin{array}{c}\text { Pre- } \\
\text { Treated }\end{array}$ & $\begin{array}{c}\text { SOF } \\
+ \\
\text { LED }\end{array}$ & $\begin{array}{c}400 \mathrm{mg} / \mathrm{jr} \\
+ \\
90 \mathrm{mg} / \mathrm{jr}\end{array}$ & 12 & $\begin{array}{c}\text { yes } \\
\text { CCI } \\
\text { (amlodipin) }\end{array}$ & $\begin{array}{l}\text { Non- } \\
\text { responders }\end{array}$ & (Q80k) & $\begin{array}{l}\text { Q24k, } \\
\text { L28T, } \\
\text { R30S }\end{array}$ & $\begin{array}{c}\text { LED, DACLA, } \\
\text { ELBAS } \\
\text { OMBIT, SIMEP, } \\
\text { VELPA } \downarrow\end{array}$ \\
\hline
\end{tabular}

Patients with DAA treatment failure haven made mutation resistance test characteristics. Legend: P: Patient; M: Masculin; F: Feminin; BMI: Body Mass Index; G: Genotype; F: Fibrosis VL: Viral Load; VR: Variant Resistance; SOF: Sofosbuvir; LED: Ledispavir; RBV: Ribavirine; Dacla: Daclatasvir; ELBAS: Elbasvir; VELPA: Velpatasvir; PIBR: Pibrentasvir; OMBIT: Ombitasvir; SIMEP: Simeprevir; PPI: Proton Pump Inhibitor; CCI: Calcium Channel Inhibitor; $\downarrow$ : Reduce Sensiblity; Drug Inter: Drug Interaction. 


\section{Discussion}

The aim of our study was to identify the factors that may be implicated in the failure of direct-acting antiviral treatment in patients with hepatitis $C$ virus in Ivory Coast. To our knowledge this study is a preliminary study conducted in sub-Saharan Africa since the advent of direct-acting antiviral therapy. The main limitation of our study was the size of our sample. Patients over the age of 50 were the most concerned ( 4 out of 5 patients). The risk factors associated with this high age were comorbidities (high blood pressure) and polymedication. Our results agreed with those of Lawson in Ivory Coast and Gautier in France [6] [14]. Indeed, in their studies, all patients with treatment failure with DAAs were over the age of 50 years, however, the history of hypertension and polypmedication were not found or mentioned for their patients. Female patients were the most represented ( 3 out of 5 cases). Lawson in his Ivory Coast study found a female predominance among patients with therapeutic failure (6 out of 11 patients). These results did not agree with most studies in France that reported a male predominance [6] [14] [15]. This could be explained by the fact that the studies of these last ones were carried out mainly on patients of Caucasian origin whose mode of contamination of the HCV was in majority by intravenous drug addiction, and the patients put under direct-acting antiviral were in male majority (sex ratio was 3 men for 1 woman). Regarding the most prevalent genotype of resistance, genotype $1 \mathrm{~b}$ was found in our study in 4 patients and genotype 2 in one patient. In the Lawson study, 6 patients out of 11 cases of direct-acting antiviral treatment failures were genotype 1 and 5 genotype 2 patients [6]. In other studies in France genotypes 4, 3, and 1a were the most common [15] [16]. This discrepancy can be explained by the fact that our study was carried out in Ivory Coast where genotypes 1 and 2 are the most frequent genotypes, unlike in France where we observe a decrease in genotypes $1 \mathrm{~b}$ and 2 in favor of genotypes 3 and 1a, and more recently genotype 4 related to African immigration and dissemination in drug groups [17]. The viral load at initiation was greater than or equal to $6 \log$ in 4 of our patients. This result is consistent with that of Lawson who found a viral load greater than or equal to $6 \log$ in 8 of his 11 patients who failed direct-acting antiviral treatment [6]. It was the same in the study by André-Garnier et al. who found a median viral load of $6.12 \log$ [15]. In the literature, the association between viral load and direct-acting antiviral failure has only been demonstrated with the combination of Grazoprevir + Elbasvir in genotype $1 \mathrm{~b}$ and $1 \mathrm{a}$ patients [1]. None of our patients had benefited from this association. Relapses were found in 3 of our patients ( 1 case of relapse at week 12 post treatment and 2 cases at week 24). In a study done in Japan by Omata et al., relapses were at the origin of all the therapeutic failures [17]. The same was true in Lawson's studies ( 4 cases of relapse at week 12 post-treatment and 7 cases at week 24 post-treatment) and Chas (13 cases of relapse in 15 cases of treatment failure) [6] [8]. We recorded a case of therapeutic escape and a case of non-response to treatment in our study. These 2 patients have in common the fact of taking con- 
comitantly drugs that can interact with direct-acting antiviral drugs. This could explain the early finding of treatment failure. Chas and Laroche also noted in their study a case of therapeutic escape without the reasons for their occurrence being explained [8] [18]. None of the patients in our study had HCV-HIV or HCV-HBV coinfection. In the Chas study, 12 out of 15 patients with $80 \%$ had co-HCV-HIV infection [8]. This difference with our results could be explained by the fact that his study was done in an infectious diseases department where most patients were generally followed for an immunodepression to HIV. A fibrosis stage less than or equal to F2 was found in 3 of our patients, and 2 of them were at a stage of cirrhosis (F4). One of our cirrhotic patients had a Child Pugh Turcott score on A5 and the other had a Child Pugh Turcott score on B9. These results are superimposable to those of Chas, who found that among the patients who failed treatment 7 out of 15 patients, or $46.7 \%$ were cirrhotic (fibrosis stage = F4) [8]. Cirrhosis has been identified as a predictor of failure with interferon unlike direct-acting antiviral [19]. All our patients had hepatic cytolysis of between 1 and 2 times normal. Regarding the treatment, 4 of our patients received the combination of sofosbuvir + ledipasvir for 12 weeks and one patient had received the sofosbuvir + ribavirin combination for 24 weeks. These treatments were instituted according to AFEF recommendations according to the period in which his patients were treated [13]. Only one patient had received prior treatment with pegylated interferon combined with ribavirin, unlike the Gautier study, where most patients who failed treatment ( 3 out of 4 ) were pretreated [14]. Lawson reported that $57.1 \%$ of failed patients were pretreated [6]. It was the same in the study done by André-Garnier et al., 4 patients out of 7 patients with treatment failure by direct-acting antiviral were pre-treated [15]. Indeed, several authors have shown that the administration and the withdrawal of alpha interferon profoundly modify the nature of circulating species of HCV. These changes were the result of successive genetic shifts, secondary to changes in the environment in which the virus replicates during treatment, resulting in many mutations [20] [21]. It is well known that resistance-associated substitutions in HCV genomes failing treatment have significantly negative effects on the efficiency of reprocessing with direct-acting antiviral [7]. Two of our patients treated with the combination sofosbuvir + ledipasvir were concomitantly taking certain known drugs such as proton pump inhibitors and calcium channel blockers (amlodipin), which may be responsible for a drug interaction that may explain the failure of these drugs. Terrault et al. reported in their study a decrease in the sustained virological response rate in patients receiving high-dose proton pump inhibitors [22]. In our study, the sequencing of NS5B strains of our failed patients found no mutation. André-Garnier and co. in their study had not found a mutation when sequencing the NS5B gene from strains of failed patients [15]. In the literature resistance to NS5B inhibitors is rare before treatment and sofosbuvir has a high resistance barrier after treatment. The selection of variants resistant to sofosbuvir in case of failure has been exceptionally reported [13]. Sequencing of 
NS5A found mutations in the Y93H, L31M, 28L, 30T, 31V, 58S and $93 \mathrm{H}$ genes in our study. The study by André-Garnier et al. found a mutation of the Y93N gene during NS5A sequencing [15]. These data are superimposable to those in the literature, which states that the variants selected during the sequencing of NS5A inhibitors have a significant "fitness" (replication capacity of mutant viruses) that could persist for several years and end up in position 28, 30, 31 and 93 [13]. In the literature, the frequency of resistant variants (except the Q80k variant) during NS3 sequencing was found in $0.1 \%$ to $3.1 \%$, and the Q80 $\mathrm{k}$ variant was mainly detected in genotype 1a patients [13]. This was the case in our study where of the 5 failed patients, 4 patients did not show mutant variants, and Q80 $\mathrm{k}$ was the only variant found in one of them. The results of the resistance mutation tests of the 4 patients who failed an NS5A inhibitor, in this case ledipasvir, had selected not only resistant variants, but also had cross-resistance between antivirals with the same target of action. This characteristic of resistance is also illustrated in the study by Alidjounou et al. [13] [23].

\section{Conclusion}

Patients with viral hepatitis $\mathrm{C}$ likely to have treatment failure had the following clinical and para-clinical profile: age of patient over 50, comorbidities (high blood pressure) and polypharmacy, female sex, genotype $1 \mathrm{~b}$, higher viral load at $6 \log \mathrm{IU} / \mathrm{ml}$, transaminases elevated at initiation of treatment (between 1 and 2 times normal), drug interactions (PPI, Amlodipine), pre-treated patients (pegylated interferon + ribavirin), genetic mutations at positions 28, 30, 31 and 93 on the viral genome including the NS5A domain, and mutations of the Q80K gene on the viral genome including the NS3 domain. It would be important to carry out this same work on a larger sample in order to properly document the characteristics of these failures and to implement the preventive measures of these and thus improve the current rates of virological effectiveness of already very high direct-acting antiviral therapy.

\section{Conflicts of Interest}

The authors declare no conflicts of interest regarding the publication of this paper.

\section{References}

[1] European Association for the Study of the Liver (2018) EASL Recommendations on Treatment of Hepatitis C. Journal of Hepatology, 69, 461-511.

[2] World Health Organization (2017) New Hepatitis Data Underscore the Urgent Need for a Global Response. WHO, Geneva. http://www.who.int/fr/

[3] Bilal, T. (2017) New Therapeutics for Chronic Viral Hepatitis C (about 63 Cases). Mohammed V University, Rabat.

[4] Yousra, A.M., Ghina, R.M., Riome, S., De Wolfe, M. and Laith, J.A.-R. (2013) The Epidemiology of Hepatitis C Virus in Egypt: A Systematic Review and Data Synthesis. BMC Infectious Diseases, 13, 288. https://doi.org/10.1186/1471-2334-13-288 
[5] Esnel, C., Desgrees du Loû, A., N'driYoman, T., Danel, C. and Larmarang, J. (2015) Viral Hepatitis B and C in Ivory Coast: Stepping up the Fight, a Pressing Need. Journal Africain d' Hépato-Gastroentérologie, 9, 94-98.

[6] Lawson-Ananissoh, A. (2016) Treatment of Chronic Viral Hepatitis C with Direct-Acting Antivirals in Côte d'Ivoire: Multicenter Observational Study. Felix Houphouet Boigny University, Ivory Coast.

[7] Kanda, T., Nirei, K., Matsumoto, N., Higuchi, T., Nakamura, H., Yamagami, H., et al. (2017) Retreatment of Patients with Treatment Failure of Direct Acting Antivirals: Focus on Hepatitis C Virus Genotype 1b. World Journal of Gastroenterology, 23, 8120-8127. https://doi.org/10.3748/wjg.v23.i46.8120

[8] Chas, J., Adda, A., Lassel, L., Lebrette, M.G., Canestri, A., Allaf, S., et al. (2017) Characteristics of Patients with Direct-Acting Antiviral (DAA) Treatment Failures in HCV-Infected Patients in a True-Life Cohort. Medicine and Infectious Diseases, 47, S72-S73. https://doi.org/10.1016/j.medmal.2017.03.178

[9] High Authority of Health (2016) Evaluation Report of Direct-Acting Antivirals in the Treatment of Hepatitis C. Opinion of the Transparency Committee of $12 \mathrm{De}$ cember 2016. HAS, Saint-Denis La Plaine.

[10] Carrion, J.A., Martinez-Bauer, E., Crespo, G., Ramirez, S., Perez-del-Pulgar, S., Garcia-Valdecasas, J.C., et al. (2009) Antiviral Therapy Increases the Risk of Bacterial Infections in HCV-Infected Cirrhotic Patients Awaiting Liver Transplantation: A Retrospective Study. Journal of Hepatology, 50, 719-728. https://doi.org/10.1016/j.jhep.2008.11.015

[11] Iacobellis, A., Siciliano, M., Perri, F., Annicchiarico, B.E., Leandro, G., Caruso, N., et al. (2007) Peginterferon Alfa-2b and Ribavirin in Patients with Hepatitis C Virus and Decompensated Cirrhosis: A Controlled Study. Journal of Hepatology, 46, 206-212. https://doi.org/10.1016/j.jhep.2006.08.020

[12] Pawlotsky, J.M. (2016) Hepatitis C Virus Resistance to Direct-Acting Antiviral Drugs in Interferon-Free Regimens. Gastroenterology, 151, 70-86. https://doi.org/10.1053/j.gastro.2016.04.003

[13] French Association for the Study of the Liver (2016) AFEF Recommendations on the Management of Viral Hepatitis C.

[14] Gautier, A. (2016) Evaluation of the Efficacy and Safety of Chronic Hepatitis C Treatment with Direct-Acting Antivirals in HIV-HCV Coinfected Patients: A Multicenter Retrospective Study. Thesis of Medicine, Faculty of Medicine and Pharmacy, Rouen.

[15] André-Garnier, E., Biland, E., Secher, S., Ruan, A., Biron, C., Ferre, V., et al. (2018) Success and Resistance to the Era of 2nd Generation HCV Antivirals in a Cohort of HIV-HCV Co-Infected Patients. Medicine and Infectious Diseases, 48, S82. https://doi.org/10.1016/j.medmal.2018.04.205

[16] Roudot-Thoraval, F. (2002) Epidemiology of Hepatitis C. Medical Sciences, 18, 315-324. https://doi.org/10.1051/medsci/2002183315

[17] Omata, M., Nishiguchi, S., Ueno, Y., Mochizuki, H., Izumi, N., Ikeda, F., et al. (2014) Sofosbuvir plus Ribavirin in Japanese Patients with Chronic Genotype 2 HCV Infection: An Open-Label, Phase 3 Trial. Journal of Viral Hepatitis, 21, 762-768. https://doi.org/10.1111/jvh.12312

[18] Laroche, H., Lions, C., Solas, C., Carrieri, P., Zaegel, O., Bregigeon, F., et al. (2017) Eradication of Chronic Active Hepatitis C in Practice: Assessment at 12 Months. Medicine and Infectious Diseases, 47, S71-S74. https://doi.org/10.1016/j.medmal.2017.03.180 
[19] Trepo, C., Merle, P., Zulim, F. and Libbey, J. (2006) Viral Hepatitis B and C. John Libbey Eurotext, Paris.

[20] Pawlotsky, J.M. (2000) Resistance of Hepatitis C Virus to Antiviral Treatments. Virology, 4, 353-359.

[21] Pawlotsky, J.M., Germanidis, G., Frainais, P.O., et al. (1999) Evolution of the Hypervariable Region of the Second Envelope Protein for Hepatitis C Virus in Chronically Infected Patients Receiving Interferon Alpha Therapy. Virology Journal, 73, 6490-6499.

[22] Terrault, N.A., Zeuzem, S., Di Biscaglie, A.M., Lim, J.K., Pockros, P.J., Frazier, L.M., et al. (2016) Effectiveness of Ledipasvir-Sofosbuvir Combination in Patients with Hepatitis C Virus Infection and Factor Associated with Sustained Virology Response. Gastroenterology, 151, 1131-1140.

https://doi.org/10.1053/j.gastro.2016.08.004

[23] Alidjinou, E.K. (2017) HCV Virus Resistance to Direct-Acting Antivirals: Communication Presented at the XXIV Regional Infectious Pathology Day, Lille, Lille University Hospital. 